\title{
APOA5 polymorphisms associated with lipid metabolism in Brazilian children and adolescents
}

\author{
E. De França', D.S.B.S. Silva', T.F.C. Silva', C.L. Dornelles ${ }^{1}$, J.G. Alves ${ }^{2}$ and \\ C.S. Alho' \\ 'Laboratório de Genética Humana e Molecular, \\ Pontifícia Universidade Católica do Rio Grande do Sul, Porto Alegre, RS, Brasil \\ ${ }^{2}$ Instituto de Medicina Integral Professor Fernando Figueira, Recife, PE, Brasil \\ Corresponding author: C.S. Alho \\ E-mail: csalho@pucrs.br \\ Genet. Mol. Res. 15 (1): gmr.15017809 \\ Received October 9, 2015 \\ Accepted December 4, 2015 \\ Published March 31, 2016 \\ DOI http://dx.doi.org/10.4238/gmr.15017809
}

\begin{abstract}
Single nucleotide polymorphisms in the APOA5 gene have been studied for their association with metabolic syndrome. Thus, elucidating the effect of the mechanism involved in APOA5 gene polymorphisms on lipid metabolism is of great importance. In this study we aimed to determine the allelic and genotypic frequencies of $-1131 \mathrm{~T}>\mathrm{C}$, Ser19Trp, and intergenic APOA4/A5 and to evaluate the association between these variants with plasma lipid levels in children and adolescents from Brazil. This study included 524 healthy children and adolescents from Mother and Child Hospital in Recife, Pernambuco, Brazil. Data were obtained on medical history, drug intake, lifestyle variables, and demography. DNA from collected samples was extracted and genotyped for the three polymorphisms. In this studied population, triglycerides and very low-density protein levels were significantly high in subjects carrying the 19WW genotype $(P<0.001)$, demonstrating the presence of this genetic risk factor in children and adolescents.
\end{abstract}

Key words: SNP; -1131T>C; Ser19Trp; APOA4/A5; Lipid metabolism 


\section{INTRODUCTION}

APOA5 is a member of the APOA1/C3/A4 gene cluster. The circulating mature form of the encoded A5 apolipoprotein is associated mainly with high-density lipoprotein (HDL) and very low-density protein (VLDL) particles (Abe et al., 2009). When human DNA was screened for APOA5 polymorphisms, more than 16 variants in young adults (18-30 years) were detected (Klos et al., 2005). The commonly analyzed variants of APOA5 are -1131T >C (rs662799), c.56C>G (rs3135506; S19W), and APOA4/A5 intergenic -12238T>C (rs1263177). Several studies have explored the association of these three polymorphisms with metabolic syndrome (Mattei et al., 2009). In general, these single nucleotide polymorphisms consistently predict high plasma triglycerides (TG), cholesterol, HDL cholesterol, LDL cholesterol, and VLDL cholesterol (Lai et al., 2005; Tai and Ordovas, 2008). The presence of the $-1131 \mathrm{C}$ allele confers increased levels of circulating triglycerides in both healthy and dyslipidemic populations (Pennacchio et al., 2001; Pennacchio et al., 2002; Ribalta et al., 2002; Talmud et al., 2002; Horinek et al., 2003). Because hypertriglyceridemia is an independent risk factor for atherogenicity and cardiovascular diseases, elucidation of the mechanism of APOA5 gene polymorphisms on lipid metabolism is of great importance. The aim of the present study was to determine the allelic and genotypic frequencies of $-1131 \mathrm{~T}>\mathrm{C}$, Ser19Trp, and intergenic APOA4/A5 and to evaluate the association between these variants with plasma lipid levels in children and adolescents from Brazil.

\section{MATERIAL AND METHODS}

The study included 524 healthy children and adolescents with ages ranging from 5 to 15 years (mean $8.9 \pm 2.9$ ) from Mother and Child Hospital in Recife, Pernambuco, Brazil. All children and their parents were born in Pernambuco. A questionnaire was completed during an interview with the parents that included details on medical history, drug intake, lifestyle variables (e.g., physical activity), and demographic data. Exclusion criteria were secondary hyperlipidemia due to renal, liver, or thyroid disease, diabetes, and a parental history of diabetes or coronary artery disease. The weight and height of subjects were measured in the morning after a 12-h fast. Height was measured to the nearest centimeter using a rigid stadiometer and weight was measured to the nearest $0.1 \mathrm{~kg}$ using a calibrated electronic scale. This study was approved by the Ethics Committee and informed consent was obtained from all participants.

DNA was extracted from the blood cells following the protocol of Lahiri and Nurnberger (1991). Genotyping was carried out using a previously reported protocol (De França et al., 2005). Data are reported as means \pm SD. A Mann-Whitney $U$ test was performed to analyze all variables according to the genotype. Hardy-Weinberg equilibrium (HWE) was determined using a chi-square test $\left(\chi^{2}\right)$. A P value $<0.05$ was assumed as significant in all tests conducted.

\section{RESULTS AND DISCUSSION}

We analyzed allelic and genotypic frequencies of the three polymorphisms. The rare allele frequencies for the $-1131 \mathrm{~T}>\mathrm{C}, \mathrm{S} 19 \mathrm{~W}$, and A4/A5 polymorphisms are $0.133,0.117$, and 0.463 , respectively. The frequency of 0.133 for the $-1131 \mathrm{~T}>\mathrm{C}$ is similar to that reported for other Brazilian populations (Chen et al., 2006). Genotype frequencies for the three polymorphisms were in HWE. The results of the analysis of all variables according to the genotype are presented in Table 1. 
In our population, TG and VLDL levels were significantly higher in subjects carrying the 19WW genotype $(P<0.001)$. The same results were also found in other studies. Can Dermidöğen et al. (2012) correlated the APOA5 S19W polymorphism with lipid parameters in a Turkish population. Also, the same rare allele was significantly associated with increased TG levels in a Spanish Mediterranean population (Ariza et al., 2010) and in Brazilians (De Andrade et al., 2011).

The A5 apolipoprotein is associated with the synthesis and removal of triglycerides. In conclusion, we presented frequencies of the three genetic variants of APOA5 and showed that the 19WW genotype was associated with higher TG and VLDL levels, demonstrating the presence of this genetic risk factor in children and adolescents.

\begin{tabular}{|c|c|c|c|c|c|c|c|c|c|c|}
\hline & $\begin{array}{c}\text { Total } \\
N(\%) \\
N=524\end{array}$ & $\begin{array}{c}\text { Age } \\
(M \pm S D) \\
N=524 \\
\end{array}$ & $\begin{array}{c}\text { BMI } \\
(M \pm S D) \\
N=524 \\
\end{array}$ & $\begin{array}{c}W / H \\
(M \pm S D) \\
N=411\end{array}$ & $\begin{array}{c}\text { TG } \\
(M \pm S D) \\
N=524 \\
\end{array}$ & $\begin{array}{c}\mathrm{TC} \\
(\mathrm{M} \pm \mathrm{SD}) \\
\mathrm{N}=524\end{array}$ & $\begin{array}{c}\mathrm{HDL} \\
(\mathrm{M} \pm \mathrm{SD}) \\
\mathrm{N}=524 \\
\end{array}$ & $\begin{array}{c}\text { TC/HDL } \\
(\mathrm{M} \pm \mathrm{SD}) \\
\mathrm{N}=524 \\
\end{array}$ & $\begin{array}{c}\text { LDL } \\
(M \pm S D) \\
N=523\end{array}$ & $\begin{array}{c}\text { VLDL } \\
(M \pm S D) \\
N=524\end{array}$ \\
\hline$\overline{\text { A4_A5 }}$ & $117(22.33)$ & $8.98 \pm 2.89$ & $19.16 \pm 4.54$ & $0.90 \pm 0.05$ & $89.26 \pm 44.19$ & $162.12 \pm 30.88$ & $45.32 \pm 9.98$ & $3.70 \pm 0.85$ & $99.10 \pm 26.11$ & $17.90 \pm 8.84$ \\
\hline $\mathrm{CC}$ & $251(47.90)$ & $9.45 \pm 2.91$ & $19.10 \pm 4.77$ & $0.90 \pm 0.05$ & $92.67 \pm 47.84$ & $161.29 \pm 32.20$ & $44.30 \pm 10.88$ & $3.80 \pm 0.84$ & $98.50 \pm 26.47$ & $18.50 \pm 9.57$ \\
\hline CT & 156 (29.77) & $8.97 \pm 2.81$ & $19.28 \pm 4.28$ & $0.89 \pm 0.05$ & $89.87 \pm 45.16$ & $164.26 \pm 31.98$ & $45.22 \pm 10.88$ & $3.70 \pm 0.85$ & $101.10 \pm 27.17$ & $18.00 \pm 9.04$ \\
\hline TT & $368(70.23)$ & $8.66 \pm 2.96$ & $18.99 \pm 4.77$ & $0.90 \pm 0.05$ & $85.73 \pm 39.56$ & $159.29 \pm 27.87$ & $46.26 \pm 10.57$ & $3.60 \pm 0.85$ & $96.30 \pm 23.88$ & $17.10 \pm 7.91$ \\
\hline $\mathrm{CC}+\mathrm{CT}$ & $407(77.67)$ & $9.12 \pm 2.85$ & $19.23 \pm 4.44$ & $0.90 \pm 0.05$ & $90.76 \pm 45.98$ & $163.32 \pm 32.04$ & $44.90 \pm 9.70$ & $3.70 \pm 0.85$ & $100.20 \pm 26.94$ & $18.20 \pm 9.20$ \\
\hline $\mathrm{TT}+\mathrm{TC}$ & & $8.85 \pm 2.87$ & $19.17 \pm 4.48$ & $0.90 \pm 0.05$ & $88.28 \pm 43.09$ & $162.36 \pm 30.53$ & $45.62 \pm 9.69$ & $3.70 \pm 0.86$ & $99.20 \pm 26.04$ & $17.70 \pm 8.63$ \\
\hline A5_S19W & 417 (79.58) & $8.98 \pm 2.89$ & $19.16 \pm 4.54$ & $0.90 \pm 0.05$ & $89.26 \pm 44.19$ & $162.12 \pm 30.88$ & $45.32 \pm 9.98$ & $3.70 \pm 0.85$ & $99.10 \pm 26.11$ & $17.90 \pm 8.84$ \\
\hline & $91(17.37)$ & $8.99 \pm 2.89$ & $19.05 \pm 4.49$ & $0.90 \pm 0.05$ & $87.15 \pm 43.26$ & $162.47 \pm 30.73$ & $45.63 \pm 10.16$ & $3.70 \pm 0.86$ & $99.60 \pm 26.18$ & $17.40 \pm 8.66$ \\
\hline SW & $16(3.05)$ & $9.16 \pm 2.86$ & $19.47 \pm 4.77$ & $0.90 \pm 0.06$ & $93.56 \pm 43.27$ & $158.51 \pm 30.89$ & $43.44 \pm 8.81$ & $3.70 \pm 0.79$ & $96.40 \pm 25.18$ & $18.70 \pm 8.66$ \\
\hline WW & 508 (96.95) & $7.63 \pm 2.94$ & $20.08 \pm 4.36$ & $0.90 \pm 0.05$ & $119.86 \pm 60.91^{a}$ & $173.44 \pm 33.42$ & $48.02 \pm 10.58$ & $3.80 \pm 1.04$ & $101.50 \pm 29.96$ & $24.00 \pm 12.17^{b}$ \\
\hline$S S+S W$ & $107(20.42)$ & $9.03 \pm 2.88$ & $19.13 \pm 4.55$ & $0.90 \pm 0.05$ & $88.29 \pm 43.29^{\mathrm{a}}$ & $161.76 \pm 30.77$ & $45.23 \pm 9.96$ & $3.70 \pm 0.85$ & $99.00 \pm 26.01$ & $17.70 \pm 8.66^{\mathrm{b}}$ \\
\hline$w W+w s$ & & $8.93 \pm 2.91$ & $19.56 \pm 4.69$ & $0.90 \pm 0.06$ & $97.49 \pm 46.94$ & $160.74 \pm 31.57$ & $44.12 \pm 9.19$ & $3.70 \pm 0.83$ & $97.10 \pm 25.86$ & $19.50 \pm 9.39$ \\
\hline$\overline{\text { A5_T- }}$ & $413(78.82)$ & $8.98 \pm 2.89$ & $19.16 \pm 4.54$ & $0.90 \pm 0.05$ & $89.26 \pm 44.19$ & $162.12 \pm 30.88$ & $45.32 \pm 9.98$ & $3.70 \pm 0.85$ & $99.10 \pm 26.11$ & $17.90 \pm 8.84$ \\
\hline $11 \overline{3} 1 \mathrm{C}$ & $83(15.84)$ & $9.14 \pm 2.93$ & $19.11 \pm 4.40$ & $0.89 \pm 0.05$ & $87.41 \pm 40.56$ & $161.21 \pm 29.85$ & $45.32 \pm 9.94$ & $3.70 \pm 0.84$ & $98.60 \pm 25.66$ & $17.50 \pm 8.12$ \\
\hline TT & $28(5.34)$ & $8.12 \pm 2.48$ & $19.53 \pm 4.83$ & $0.92 \pm 0.04$ & $99.42 \pm 60.69$ & $167.49 \pm 33.34$ & $46.21 \pm 10.43$ & $3.80 \pm 0.98$ & $101.40 \pm 27.59$ & $19.90 \pm 12.14$ \\
\hline CT & $496(94.66)$ & $9.14 \pm 2.97$ & $18.72 \pm 5.65$ & $0.89 \pm 0.05$ & $86.50 \pm 34.02$ & $159.64 \pm 37.39$ & $42.68 \pm 9.02$ & $3.80 \pm 0.59$ & $99.70 \pm 28.78$ & $17.30 \pm 6.81$ \\
\hline CC & $111(21.18)$ & $8.97 \pm 2.89$ & $19.18 \pm 4.47$ & $0.90 \pm 0.05$ & $89.42 \pm 44.72$ & $162.26 \pm 30.52$ & $45.47 \pm 10.02$ & $3.70 \pm 0.86$ & $99.00 \pm 25.98$ & $17.90 \pm 8.95$ \\
\hline $\mathrm{TT}+\mathrm{TC}$ & & $8.38 \pm 2.64$ & $19.32 \pm 5.04$ & $0.91 \pm 0.05$ & $96.16 \pm 55.34$ & $165.51 \pm 34.40$ & $45.32 \pm 10.17$ & $3.80 \pm 0.89$ & $101.00 \pm 27.78$ & $19.20 \pm 11.07$ \\
\hline $\mathrm{CC}+\mathrm{CT}$ & & & & & & & & & & \\
\hline
\end{tabular}

a19WW versus 19SS $+19 S W=P<0.001$. ${ }^{b} 19 W W$ versus $19 S S+19 S W=P<0.001 . M \pm S D:$ mean \pm standard deviation; BMI: body mass index; W/H: waist-to-hip ratio; TG: triglycerides; TC: total cholesterol; HDL: high-density lipoprotein cholesterol; LDL: low-density lipoprotein cholesterol; VLDL: very low-density lipoprotein cholesterol.

\section{Conflicts of interest}

The authors declare no conflict of interest.

\section{ACKNOWLEDGMENTS}

The authors are grateful to Francis Jackson Paludo for statistical support and to Emilia da Silva Borges in the Haematology and Haemotherapy Centre of Pernambuco (HEMOPE) for assistance with blood collection. We would also like to thank Pietra Graebin. Research supported by MCT/CNPq/MS-SCTIE-DECIT/SAS-DAB51/2005.

\section{REFERENCES}

Abe Y, Okada T, Kuromori Y, Hara M, et al. (2009). Apolipoprotein A-V is a potent modulator of HDL and VLDL components in preadolescent children. J. Atheroscler. Thromb. 16: 121-126.http://dx.doi.org/10.5551/jat.E356

Ariza MJ, Sánchez-Chaparro MA, Barón FJ, Hornos AM, et al. (2010). Additive effects of LPL, APOA5 and APOE variant combinations on triglyceride levels and hypertriglyceridemia: results of the ICARIA genetic sub-study. BMC Med. Genet. 11: 66.http://dx.doi.org/10.1186/1471-2350-11-66

Can Demirdöğen B, Şahin E, Türkanoğlu Özçelik A, Bek S, et al. (2012). Apolipoprotein A5 polymorphisms in Turkish population: association with serum lipid profile and risk of ischemic stroke. Mol. Biol. Rep. 39: 10459-10468.http://dx.doi. org/10.1007/s11033-012-1926-z 
Chen ES, Cendoroglo MS, Ramos LR, Araujo LM, et al. (2006). APO A-V-1131T-->C polymorphism frequency and its association with morbidity in a Brazilian elderly population. Clin. Chem. Lab. Med. 44: 32-36.http://dx.doi.org/10.1515/ CCLM.2006.007

De Andrade FM, Maluf SW, Schuch JB, Voigt F, et al. (2011). The influence of the S19W SNP of the APOA5 gene on triglyceride levels in southern Brazil: interactions with the APOE gene, sex and menopause status. Nutr. Metab. Cardiovasc. Dis. 21: 584-590.http://dx.doi.org/10.1016/j.numecd.2009.12.013

De França E, Alves JG and Hutz MH (2005). APOA1/C3/A4 gene cluster variability and lipid levels in Brazilian children. Braz. J. Med. Biol. Res. 38: 535-541.http://dx.doi.org/10.1590/S0100-879X2005000400006

Horínek A, Vráblík M, Ceska R, Adámková V, et al. (2003). T-1131-->C polymorphism within the apolipoprotein AV gene in hypertriglyceridemic individuals. Atherosclerosis 167: 369-370.http://dx.doi.org/10.1016/S0021-9150(03)00022-4

Klos KL, Hamon S, Clark AG, Boerwinkle E, et al. (2005). APOA5 polymorphisms influence plasma triglycerides in young, healthy African Americans and whites of the CARDIA Study. J. Lipid Res. 46: 564-571.http://dx.doi.org/10.1194/jlr. M400437-JLR200

Lahiri DK and Nurnberger JI, Jr. (1991). A rapid non-enzymatic method for the preparation of HMW DNA from blood for RFLP studies. Nucleic Acids Res. 19: 5444.http://dx.doi.org/10.1093/nar/19.19.5444

Lai CQ, Parnell LD and Ordovas JM (2005). The APOA1/C3/A4/A5 gene cluster, lipid metabolism and cardiovascular disease risk. Curr. Opin. Lipidol. 16: 153-166.http://dx.doi.org/10.1097/01.mol.0000162320.54795.68

Mattei J, Demissie S, Tucker KL and Ordovas JM (2009). Apolipoprotein A5 polymorphisms interact with total dietary fat intake in association with markers of metabolic syndrome in Puerto Rican older adults. J. Nutr. 139: 2301-2308.http://dx.doi. org/10.3945/jn.109.109900

Pennacchio LA, Olivier M, Hubacek JA, Cohen JC, et al. (2001). An apolipoprotein influencing triglycerides in humans and mice revealed by comparative sequencing. Science 294: 169-173.http://dx.doi.org/10.1126/science.1064852

Pennacchio LA, Olivier M, Hubacek JA, Krauss RM, et al. (2002). Two independent apolipoprotein A5 haplotypes influence human plasma triglyceride levels. Hum. Mol. Genet. 11: 3031-3038.http://dx.doi.org/10.1093/hmg/11.24.3031

Ribalta J, Figuera L, Fernández-Ballart J, Vilella E, et al. (2002). Newly identified apolipoprotein AV gene predisposes to high plasma triglycerides in familial combined hyperlipidemia. Clin. Chem. 48: 1597-1600.

Tai ES and Ordovas JM (2008). Clinical significance of apolipoprotein A5. Curr. Opin. Lipidol. 19: 349-354.http://dx.doi. org/10.1097/MOL.0b013e328304b681

Talmud PJ, Hawe E, Martin S, Olivier M, et al. (2002). Relative contribution of variation within the APOC3/A4/A5 gene cluster in determining plasma triglycerides. Hum. Mol. Genet. 11: 3039-3046.http://dx.doi.org/10.1093/hmg/11.24.3039 